\title{
Short-term effects of dietary sodium intake on bone metabolism in postmenopausal women measured using urinary deoxypyridinoline excretion
}

\author{
BY GEORG LIETZ* $\uparrow$, ALISON AVENELL $\ddagger$ AND SIMON P. ROBINS \\ The Rowett Research Institute, Greenburn Road, Bucksburn, Aberdeen AB21 9SB
}

(Received 26 September 1996-Revised 14 January 1997-Accepted 15 January 1997)

\begin{abstract}
The influence of $\mathrm{Na}$ load on bone metabolism was investigated in postmenopausal women using urinary deoxypyridinoline (DPD) as a marker of bone resorption. In a cross-over study, fourteen postmenopausal women were divided into two groups of seven. A fixed diet providing $816 \mathrm{mg} \mathrm{Ca} / \mathrm{d}$ with either 60 or $170 \mathrm{mmol} \mathrm{Na} / \mathrm{d}$ was consumed. At the end of an $8 \mathrm{~d}$ period the groups switched diets for a further $8 \mathrm{~d}$ period. Urine was collected daily for the last $4 \mathrm{~d}$ of each period. There was no significant difference in DPD excretion between high-Na and low-Na diets $(129 \mathrm{nmol} / \mathrm{d} v .132 \mathrm{nmol} / \mathrm{d}$; $\boldsymbol{P}=\mathbf{0}$.18). There was, however, a significant relationship $(P=0.02)$ between the changes in DPD excretion and urinary $\mathrm{Ca}$. Plasma $\mathrm{Mg}$ fell from 0.83 to $0.81 \mathrm{mmol} / \mathrm{l}$ on the high $\mathrm{Na}$ intake $(P<0.001)$, but there was no significant effect on plasma Ca or intact parathyroid hormone levels. It is concluded that varying dietary $\mathrm{Na}$ intake may affect $\mathrm{Ca}$ and $\mathrm{Mg}$ metabolism, but we were unable to demonstrate an effect on bone resorption at the levels of intake used.
\end{abstract}

Deoxypyridinoline: Sodium: Bone: Postmenopausal women

A strong positive relationship between urinary $\mathrm{Na}$ and $\mathrm{Ca}$ excretion exists in free-living normal men (McCarron et al. 1981; Breslau et al. 1982; Castenmiller et al. 1985; Shortt et al. 1988; Chan et al. 1992), premenopausal women (Breslau et al. 1982; Shortt et al. 1988) and postmenopausal women (Breslau et al. 1985; Nordin \& Polley, 1987; McParland et al. 1989; Zarkadas et al. 1989).

To examine the influence of $\mathrm{Na}$ on bone turnover, some studies used only urinary $\mathrm{Ca}$ excretion (Shortt et al. 1988; Zarkadas et al. 1989), whereas others used urinary hydroxyproline as a marker for bone resorption (Castenmiller et al. 1985; McParland et al. 1989; Chan et al. 1992). However, hydroxyproline is not specific for bone and is, therefore, an insensitive marker for bone resorption. Large amounts of hydroxyproline are metabolized in the liver, and the amount excreted is dependent on the dietary intake of collagen (Robins, 1982; Delmas, 1992). The pyridinium cross-links of collagen, pyridinoline (PYD) and deoxypyridinoline (DPD), have been shown to be more specific urinary markers of bone resorption, both in Paget's disease of bone and in primary hyperparathyroidism (Robins et al. 1991; Eyre, 1992). Furthermore, the cross-link markers have the advantage that they are unaffected by dietary sources of collagen (Colwell et al. 1990). PYD is found in the collagen of cartilage, bone and in smaller amounts in other connective tissues. In contrast, DPD has only been found in significant amounts in type I

* Present address: Oxford Brookes University, School of Biological and Molecular Sciences, Gipsy Lane Campus, Headington, Oxford OX3 0BP.

$\dagger$ For reprints.

† Present address: Department of Clinical Biochemistry, Royal Infirmary of Edinburgh, Lauriston Place, Edinburgh EH3 9YW. 
collagen of bone and is, therefore, a promising marker for the assessment of bone resorption (Delmas, 1992).

The aim of the present study was to examine the influence of $\mathrm{Na}$ intake on bone resorption, as measured by urinary DPD excretion.

\section{METHODS \\ Design}

Fourteen postmenopausal women (mean age 62.3 (range 50-70) years) were selected for the study. Exclusion criteria were: smoking, chronic illness or drugs known to affect bone metabolism, any fracture since the menopause, not less than 2 years past the menopause. Characteristics of the subjects are shown in Table 1.

The study was designed in two periods, each of $8 \mathrm{~d}$, in which $\mathrm{NaCl}$ was given with the diet either in a low or high concentration, the amounts being 60 and $170 \mathrm{mmol} \mathrm{Na} / \mathrm{d}$ respectively. In this cross-over study volunteers were divided into two groups of seven. At the end of the first period, the groups switched diets for the second period (Fig. 1). Subjects were instructed to collect $24 \mathrm{~h}$ urine for the duration of the study. Only urine samples collected in the last $4 \mathrm{~d}$ of each treatment period were analysed, to allow a washout period as previously suggested (Shortt \& Flynn, 1990). After an overnight fast, blood samples were taken at 08.00 hours and blood pressure and weight were measured on days $1,5,9,13$ and 17 (Fig. 1).

Ethical permission was obtained from the Joint Ethical Committee of the Grampian Health Board and the University of Aberdeen.

\section{Diet}

The diet consisted of a $2 \mathrm{~d}$ rotation with amounts of energy and nutrients kept constant. Nutrient intakes, other than $\mathrm{NaCl}$, were identical for each $8 \mathrm{~d}$ period. For each subject, total energy expenditure was calculated using BMR equations and the physical activity level of 1.4 (Department of Health, 1991). The exact amounts for the major nutrients are shown in Table 2. Diet prescription sheets were used to convert the 8.3 MJ standard diet into the calculated energy requirements. Amounts of energy, protein, carbohydrate and $\mathrm{Ca}$ in the diet were based on the report of national consumption of household food in Scotland 1990 (Ministry of Agriculture, Fisheries and Food, 1990). Dietary fibre was close to that reported by the Scottish Heart Health Study (Bolton-Smith et al. 1991). The amount of $\mathrm{Na}$ in the

Table 1. Characteristics of the subjects participating in the study

(Mean values with their standard errors and ranges)

\begin{tabular}{lccc}
\hline \multicolumn{1}{c}{ Subjects } & Mean & SEM & Range \\
\hline Age (years) & $62 \cdot 3$ & $1 \cdot 5$ & $50-70$ \\
Wt (kg) & $66 \cdot 4$ & $2 \cdot 3$ & $50 \cdot 1-80 \cdot 2$ \\
BMI (kg/m ${ }^{2}$ Age at menopause (years) & $26 \cdot 1$ & $0 \cdot 8$ & $20 \cdot 9-30 \cdot 3$ \\
No. of years since menopause & $48 \cdot 2$ & $0 \cdot 9$ & $42-54$ \\
Blood pressure (mm Hg): & $14 \cdot 5$ & $2 \cdot 2$ & $2-25$ \\
$\quad$ Systolic & 129 & 4 & $104-152$ \\
Diastolic & 81 & 2 & $70-94$ \\
\hline
\end{tabular}


Group A

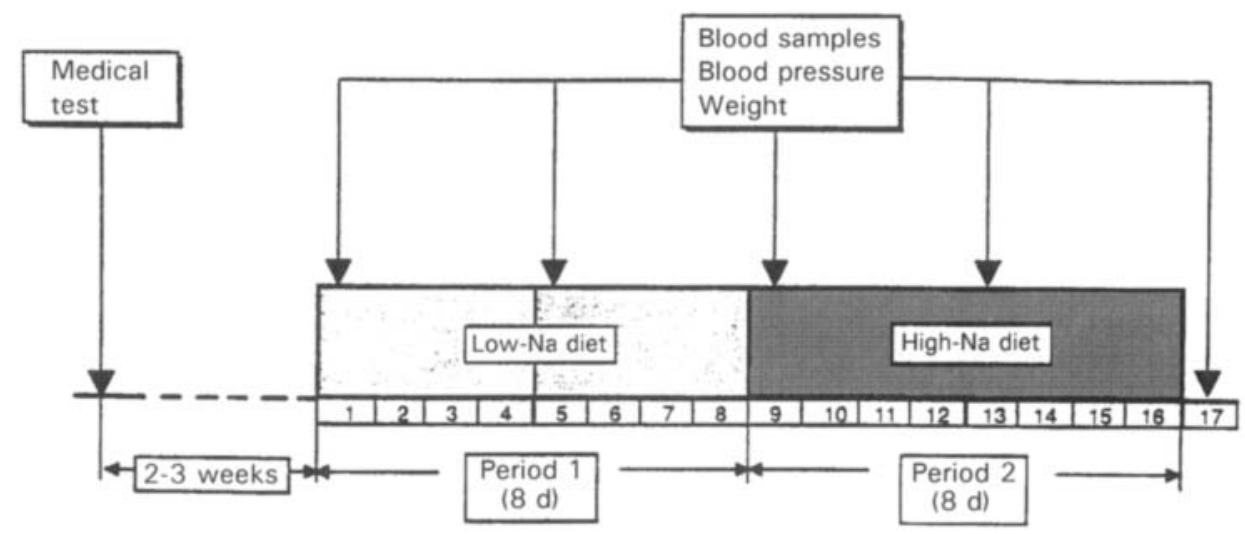

Group B

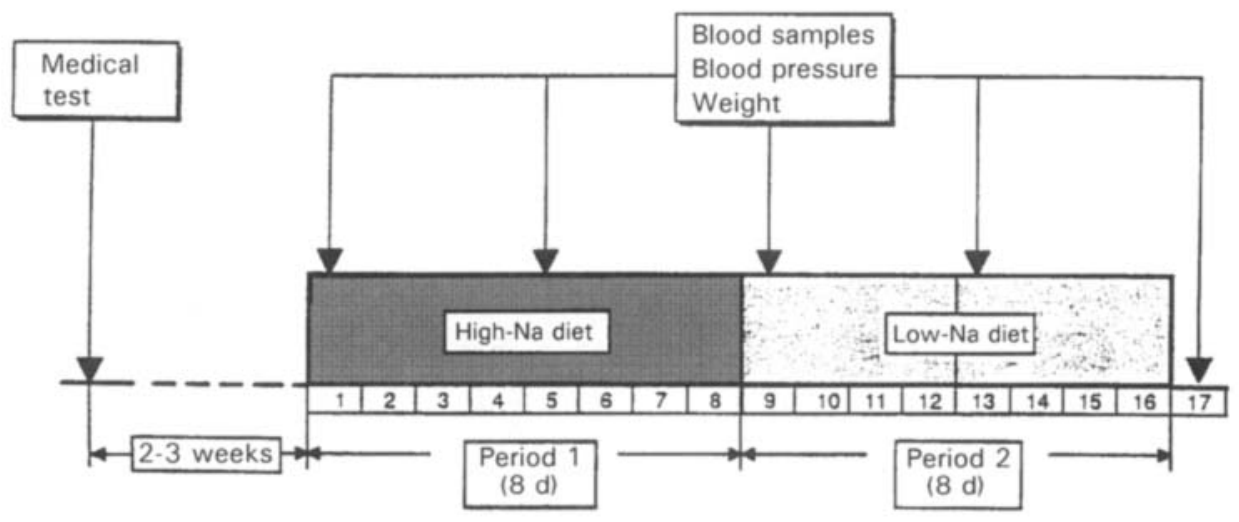

Fig. 1. Schedule of study design.

high $\mathrm{Na}$ period was similar to the mean urinary $\mathrm{Na}$ excretion in Scotland (Smith et al. 1988), and the amount in the low-Na period was close to the reference nutrient intake $(70 \mathrm{mmol} \mathrm{Na} / \mathrm{d}$ ) for adults (Department of Health, 1991). $\mathrm{Na}$ was weighed out as $\mathrm{NaCl}$ and incorporated into the chosen food items. Drinking water was not restricted, but all water used was demineralized. Because caffeine may increase urinary $\mathrm{Ca}$ excretion, only decaffeinated tea or coffee was allowed. Volunteers drank the same amount of tea or coffee every day.

\section{Collection and preparation of samples}

The urine samples were stored at $4^{\circ}$ until the end of the $24 \mathrm{~h}$ collection period. Then they were acidified with $10 \mathrm{ml} 6 \mathrm{M}-\mathrm{HCl}$ and finally stored at $-20^{\circ}$ until required. Blood was collected by venipuncture into vacutainer tubes. Plasma was obtained following centrifugation at $7000 \mathrm{rev} . / \mathrm{min}$ for $10 \mathrm{~min}$ and immediately stored at $-70^{\circ}$ until required. 
Table 2. Total nutrient content of diet compared with Ministry of Agriculture, Fisheries and Food (MAFF; 1991) report and results from the Scottish Heart Health Study (SHHS; Bolton-Smith et al. 1991)

\begin{tabular}{|c|c|c|c|c|}
\hline \multirow[b]{2}{*}{ Nutrient } & \multicolumn{2}{|c|}{ Diet* } & \multicolumn{2}{|c|}{ Nutrient intake from: } \\
\hline & Day 1 & Day 2 & MAFF & SHHS \\
\hline Energy: kcal & 1985 & 1984 & 1980 & \\
\hline $\mathrm{kJ}$ & 8343 & 8337 & 8300 & \\
\hline Carbohydrate (g) & $245 \cdot 3$ & $244 \cdot 5$ & 244.0 & \\
\hline Lactose $(\mathrm{g})$ & $16 \cdot 1$ & 16.9 & & \\
\hline Sugars $(g)$ & 59.5 & 49.9 & & \\
\hline Starch and dextrin $(\mathrm{g})$ & $169 \cdot 6$ & $177 \cdot 6$ & & \\
\hline Fibre (Southgate) $\dagger(\mathrm{g})$ & $16 \cdot 4$ & $19 \cdot 1$ & & $18 \cdot 0-20-5$ \\
\hline Protein $(\mathrm{N} \times 6.25)(\mathrm{g})$ & $65 \cdot 7$ & $66 \cdot 2$ & $65 \cdot 8$ & \\
\hline Total N (g) & $10 \cdot 7$ & $10 \cdot 8$ & & \\
\hline Fat $(\mathrm{g})$ & 89.3 & 89.2 & $89 \cdot 0$ & \\
\hline $\mathrm{P}: \mathrm{S}$ quotient & 0.29 & 0.29 & & $0.28-0.31$ \\
\hline $\mathrm{Ca}: \mathrm{mg}$ & $816 \cdot 2$ & $815 \cdot 6$ & 840 & \\
\hline mmol & $20 \cdot 4$ & $20 \cdot 3$ & & \\
\hline Phosphate: mg & 1095 & 1070 & & \\
\hline mmol & 35.4 & 34.5 & & \\
\hline $\mathrm{P}(\mathrm{mmol}): \mathrm{Ca}(\mathrm{mmol})$ & 1.73 & 1.69 & & \\
\hline $\mathrm{Mg}(\mathrm{mg})$ & 214 & 227 & & \\
\hline $\mathrm{K}(\mathrm{mg})$ & 2401 & 2746 & & \\
\hline
\end{tabular}

$P: S$, polyunsaturated : saturated fat.

* For detailed daily menus, contact author.

$\dagger$ Water-soluble polysaccharides, hemicellulose, cellulose and lignin, according to Southgate (1969).

\section{Experimental techniques}

Radioimmunoassay. The Allegro Intact PTH Immunoassay (Nichols Institute Diagnostics, San Juan Capistrano, CA, USA), used for quantitative determination of human intact parathyroid hormone in serum, is a two-site immunoradiometric assay for the measurement of the biologically-intact eighty-four amino acid peptide. The radioactivity was measured using the Cobra-Gamma counting system (Packard Instrument Ltd, Downers Grove, IL, USA). Every sample was analysed in duplicate in the same run and the intra-assay CV was $3.5 \%$.

Plasma calcium and magnesium. Both $\mathrm{Ca}$ and $\mathrm{Mg}$ were analysed in duplicate using the KONE Analyser (Labmedics Ltd, Stockport, Cheshire) according to methods previously described (Bauder, 1981; Pesce \& Kaplan, 1987). Intra-assay CV were 2.2 and $2.0 \%$ for $\mathrm{Ca}$ and $\mathrm{Mg}$ respectively. All samples were measured together in the same run.

Urinary calcium, magnesium, sodium and potassium. Ca was analysed in duplicate as previously described (Ray Sarkar \& Chauhan, 1967). Intra- and inter-assay CV were 2.4 and $7.3 \%$ respectively. $\mathrm{Mg}$ was analysed in duplicate using the Technicon AutoAnalyzer (Technicon Instruments Co. Ltd, Basingstoke, Hants) as previously described (Gitelman et al. 1966). Intra- and inter-assay CV for $\mathrm{Mg}$ were found to be 2.6 and $10.5 \%$ respectively. $\mathrm{Na}$ and $\mathrm{K}$ were analysed in duplicate using the Technicon Flame Photometer (Technicon Instruments Co. Ltd) according to Technicon Instruments Co. Ltd (1971). Intra- and interassay $\mathrm{CV}$ for $\mathrm{Na}$ were 4.2 and $7.1 \%$ and for $\mathrm{K} 4.2$ and $10.3 \%$ respectively. 
Urinary pyridinoline and deoxypyridinoline. Samples were analysed in duplicate using ion-paired reversed-phase HPLC directly linked to an automatic sample preparation system with extraction columns (Gilson ASPEC; Anachem, Luton, Beds.) together with the use of an internal standard as previously described (Pratt et al. 1992). Intra- and inter-assay CV were respectively, for pyridinoline 3.2 and $6.1 \%$, and for deoxypyridinoline 6.3 and $5.0 \%$.

Validity of the urine collection. Urine collections $(24 \mathrm{~h})$ were checked for completeness by using creatinine excretion. Creatinine was analysed in duplicate as previously described (Stevens et al. 1953). Intra- and inter-assay CV were 2.6 and $5.8 \%$ respectively. The overall mean was found to be $978 \mathrm{mg} / \mathrm{d}$. The intra-individual $\mathrm{CV}$ of creatinine averaged $8.1 \%$. Collections were designated incomplete when their creatinine excretion was outside two standard deviations from their mean. From 223 samples, ten were presumed incomplete.

\section{Statistical analysis}

Data are presented as means with their standard errors. Comparison between the periods and between the groups was performed using ANOVA. The statistical package used was Genstat (Lawes Agricultural Trust, 1987).

\section{RESULTS}

Urinary $\mathrm{Ca}$ excretion was significantly higher during the high- $\mathrm{Na}$ treatment period than the low-Na treatment period ( $P<0.001$; Table 3). Urinary $\mathrm{Mg}$ tended to increase with $\mathrm{Na}$ loading, but the difference was not statistically significant $(P=0.08$; Table 3$)$.

There was no significant difference in DPD or PYD excretion on varying the Na load (Table 3). A positive correlation was found between changes in mean urinary $\mathrm{Ca}$ and mean DPD excretion across the two diet periods ( $r 0.62, P<0.02$; Fig. 2). There was no significant effect of $\mathrm{Na}$ loading on urinary volume or creatinine excretion (Table 3 ).

Plasma Ca did not change across the diet periods, but there was a significant fall in $\mathrm{Mg}$ levels with Na loading $(P<0.001$; Table 4$)$. PTH was measured in only three volunteers from each group, and no change with dietary $\mathrm{Na}$ was found (Table 4).

The CV for the daily DPD excretion averaged $9.5 \%$, lower than the value of $24 \%$ obtained previously (McLaren et al. 1993), which probably relates to the improved precision of the assay using an internal standard.

There was a small, but not significant, rise in diastolic and systolic blood pressure with Na loading (Table 4).

\section{DISCUSSION}

Many dietary factors are thought to influence Ca homeostasis, e.g. vitamin D, P, caffeine, protein, $\mathrm{Na}$ and dietary fibre (in part by the action of phytate). It is important, therefore, to keep all other dietary influences on Ca homeostasis constant when studying the influence of $\mathrm{Na}$ on bone and $\mathrm{Ca}$ metabolism. It was stressed that adaptation of the body to changes in $\mathrm{Ca}$ intake can take from 6 to 18 months (Zarkadas et al. 1989). The diet in the present study conformed with average Scottish intakes for all major nutrients, and it is hoped that the effects of adaptation were reasonably small. We also chose to examine the effect of changing $\mathrm{Na}$ intakes from the current average to a level close to the reference nutrient 
Table 3. The effects of two levels of dietary sodium (as sodium chloride) supplements on the urinary excretion of calcium, magnesium, potassium, creatinine, pyridinoline and deoxypyridinoline averaged from four $24 \mathrm{~h}$ urine collections in postmenopausal women*

(Mean values with their standard errors)

\begin{tabular}{|c|c|c|c|c|c|}
\hline & \multicolumn{4}{|c|}{ Na content in diet $(\mathrm{mmol} / \mathrm{d})$} & \multirow{3}{*}{$\begin{array}{c}\text { Statistical } \\
\text { significance of } \\
\text { difference: } \\
P\end{array}$} \\
\hline & \multicolumn{2}{|c|}{60} & \multicolumn{2}{|c|}{170} & \\
\hline & Mean & $\mathrm{SE}$ & Mean & SE & \\
\hline $\mathrm{Na}(\mathrm{mmol} / \mathrm{d})$ & $39 \cdot 1$ & 1.4 & 130.4 & 2.0 & $<0.001$ \\
\hline $\mathrm{Ca}(\mathrm{mmol} / \mathrm{d})$ & 4.0 & $0 \cdot 3$ & 4.5 & 0.4 & $<0.001$ \\
\hline $\mathrm{Mg}(\mathrm{mmol} / \mathrm{d})$ & $3 \cdot 2$ & 0.2 & 3.4 & $0 \cdot 3$ & 0.08 \\
\hline $\mathrm{K}(\mathrm{mmol} / \mathrm{d})$ & $40 \cdot 7$ & 1.7 & 41.9 & 1.6 & NS \\
\hline Creatinine $(\mathrm{mg} / \mathrm{d})$ & 967 & 26 & 979 & 28 & NS \\
\hline Pyridinoline $(\mathrm{nmol} / \mathrm{d})$ & 476 & 22 & 465 & 25 & NS \\
\hline Deoxypyridinoline (nmol/d) & 132 & 7 & 129 & 7 & NS \\
\hline Urine output $(\mathrm{g} / \mathrm{d})$ & 1971 & 138 & 2002 & 141 & NS \\
\hline
\end{tabular}

* For details of subjects and procedures, see Table 1, Fig. 1 and pp. 74-77.

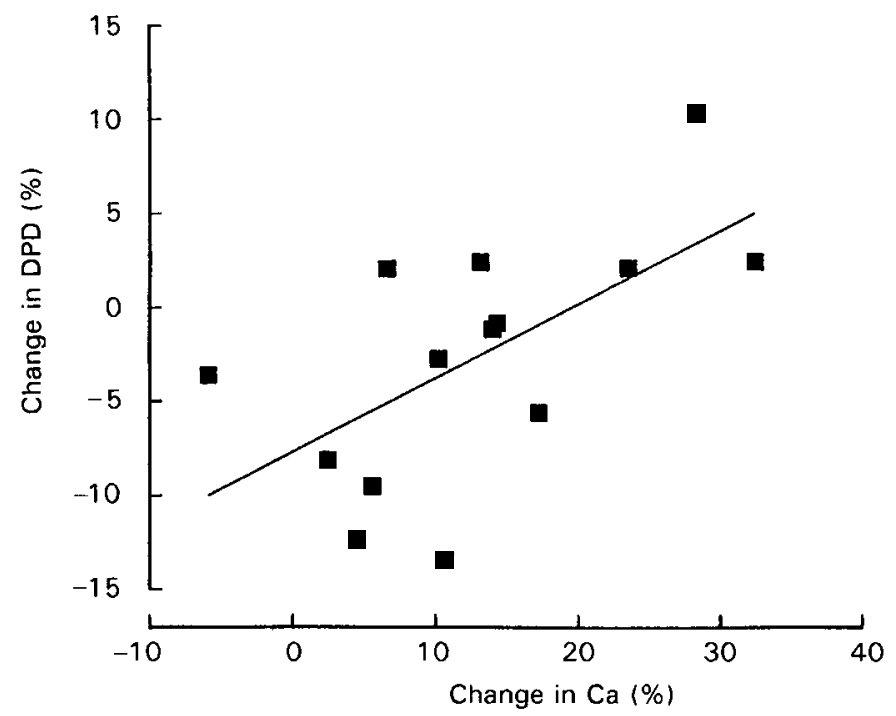

Fig. 2. Correlation between urinary calcium and deoxypyridinoline (DPD) excretion in postmenopausal women for two diet periods of $8 \mathrm{~d}$ each in which they received sodium (as sodium chloride) supplements of $60 \mathrm{or} 170 \mathrm{mmol} / \mathrm{d}$ in a crossover study. For details of subjects and procedures, see Table 1, Fig. 1 and pp. 74-77, $r 0.616 ; P<0.019$.

intake of the Department of Health (1991). Thus, we did not subject our volunteers to extremes of $\mathrm{Na}$ intake.

It has been known for a long time that high intakes of Na cause hypercalciuria in healthy and osteoporotic subjects. In our study urinary $\mathrm{Ca}$ increased by $0.55 \mathrm{mmol} / \mathrm{d}$ per $100 \mathrm{mmol} / \mathrm{d}$ increase in urinary $\mathrm{Na}$. Similar results were obtained in postmenopausal women, with an increase in urinary $\mathrm{Ca}$ of about 0.58 (McParland et al. 1989) and 0.6 (Zarkadas et al. 1989) $\mathrm{mmol} / \mathrm{d}$ per $100 \mathrm{mmol} / \mathrm{d}$ increase in urinary $\mathrm{Na}$. 
Table 4. The effects of two levels of dietary sodium (as sodium chloride) supplements on blood pressure, plasma calcium, magnesium and parathyroid hormone (PTH) in postmenopausal women*

(Mean values with their standard errors)

\begin{tabular}{|c|c|c|c|c|c|}
\hline & \multicolumn{4}{|c|}{ Na content in diet $(\mathrm{mmol} / \mathrm{d})$} & \multirow{3}{*}{$\begin{array}{c}\text { Statistical } \\
\text { significance of } \\
\text { difference: } \\
P\end{array}$} \\
\hline & \multicolumn{2}{|c|}{60} & \multicolumn{2}{|c|}{170} & \\
\hline & Mean & SE & Mean & SE & \\
\hline \multicolumn{6}{|c|}{ Blood pressure ( $\mathrm{mm} \mathrm{Hg}$ ) } \\
\hline Systolic & 128 & 3 & 131 & 4 & NS \\
\hline Diastolic & 76 & 2 & 79 & 2 & NS \\
\hline $\mathrm{Ca}(\mathrm{mmol} / \mathrm{l})$ & $2 \cdot 36$ & 0.01 & 2.35 & $0 \cdot 01$ & NS \\
\hline $\mathrm{Mg}(\mathrm{mmol} / \mathrm{l})$ & 0.83 & 0.01 & 0.81 & 0.01 & $<0.001$ \\
\hline PTH $(\mathrm{pg} / \mathrm{ml}) \dagger$ & 34.6 & $6 \cdot 6$ & $34 \cdot 7$ & 6.4 & NS \\
\hline
\end{tabular}

* For details of subjects and procedures, see Table 1, Fig. 1 and pp. 74-77.

$\uparrow$ Measured for six volunteers only.

We found no significant change in DPD excretion on varying $\mathrm{Na}$ load. This observation appears to contrast with the results of the study of McParland et al. (1989), where hydroxyproline was reported to increase after Na loading. Need et al. (1991) also found that $\mathrm{Na}$ restriction in postmenopausal women on a gelatin-free diet was associated with a fall in hydroxyproline excretion. On the other hand, studies in younger subjects have found both an increase (Chan et al. 1992) and no change (Castenmiller et al. 1985) in hydroxyproline excretion with $\mathrm{Na}$ loading. It is possible that the lower $\mathrm{Na}$ load used in our study is responsible for the lack of change in DPD excretion across the two dietary treatments. Another explanation might be the relatively shorter duration of this study. Even though $\mathrm{Na}$ balance was achieved after 3-4d, bone remodelling did not appear to increase after $8 \mathrm{~d}$. On the other hand, McParland et al. (1989) and Chan et al. (1992) showed an increase in hydroxyproline after $10 \mathrm{~d}$, and a recent study looking at the effect of short-term starvation on bone turnover (Grinspoon et al. 1995) demonstrated a significant decline in bone formation markers after only $\mathbf{4 d}$. However, hydroxyproline used in previous studies is known to be a much-less-sensitive marker of bone resorption than urinary DPD, and the changes observed in previous studies, therefore, do not necessarily reflect alterations only in skeletal metabolism. Increases in hydroxyproline excretion could occur from many other connective tissues, including degradation of newly-formed collagen, or from an alteration in the liver catabolism of hydroxyproline.

It was stressed by Need $e t$ al. (1991) that subjects with an initial $\mathrm{Na}$ : creatinine value of less than $15 \mathrm{mmol} / \mathrm{mmol}$ are not likely to show a significant decrease in hydroxyproline excretion on a modest Na-restricted diet. Since participants in the present study had an initial $\mathrm{Na}$ : creatinine value of $10 \mathrm{mmol} / \mathrm{mmol}$ on day 1 of the study, very little change in DPD excretion might be expected. The one subject in our study who had an initial sodium:creatinine value over $15 \mathrm{mmol} / \mathrm{mmol}$ manifested the largest increase in DPD excretion with $\mathrm{Na}$ load. Nordin \& Polley (1987) found a significant effect of $\mathrm{Na}$ restriction on fasting urinary $\mathrm{Ca}$ values only when the initial $\mathrm{Na}$ : creatinine value was greater than $15 \mathrm{mmol} / \mathrm{mmol}$, which was the case in only $25 \%$ of postmenopausal women.

It is noteworthy that we found a significant relationship betwen $\mathrm{Na}$-induced changes in DPD and Ca concentrations. This suggests that the new bone marker may help to identify those individuals who are susceptible to the detrimental effects of increased $\mathrm{Na}$ intake on bone metabolism. 
Increased urinary $\mathrm{Ca}$ excretion has been suggested to depress plasma $\mathrm{Ca}$, leading to enhanced PTH secretion which seeks to maintain plasma Ca by increasing bone resorption (Shortt \& Flynn, 1990). Furthermore, Breslau et al. (1982) found that increasing dietary $\mathrm{Na}$ enhanced fractional gut $\mathrm{Ca}$ absorption in young men and women. This could also help to explain the increase in urinary $\mathrm{Ca}$. Since this response did not occur in two subjects with hypoparathyroidism, they suggested that this response was related to PTH stimulation of 1,25-dihydroxycholecalciferol production. However, we were unable to detect any significant change in PTH in our small subsample, and in a later paper, Breslau et al. (1985) also found no increase in PTH in a study with osteoporotic women, and suggested that the PTH response to Na-induced calciuria may be slow. Zarkadas et al (1989) also reported no increase in PTH in postmenopausal women. However, when PTH was measured by urinary cAMP in postmenopausal women, an increase after Na loading was detected. Despite apparent increases in PTH, 1,25-dihydroxycholecalciferol and Ca absorption did not increase, suggesting an impaired PTH-vitamin D axis (McParland et al. 1989).

We did not measure 25-hydroxy- or 1,25-dihydroxycholecalciferol. The PTH measurements from the six subjects would suggest that they did not have secondary hyperparathyroidism as a consequence of vitamin D deficiency, the study being conducted during the winter. We also could not assess whether changes in 1,25-dihydroxycholecalciferol could have influenced $\mathrm{Ca}$ absorption.

The dependence of urinary $\mathrm{Ca}$ excretion on urinary $\mathrm{Na}$-excretion has been attributed to the existence of linked or common re-absorption pathways for both ions in the proximal tubule and thick ascending loop of Henle (Shortt \& Flynn, 1990). However, more recently, MacGregor \& Cappuccio (1993) have suggested that $\mathrm{Na}$-induced calciuria results from expansion of central blood volume, with a slight fall in plasma $\mathrm{Ca}$, stimulating $\mathrm{PTH}$ secretion. They suggested that subjects with essential hypertension have an inherited defect in renal clearance of $\mathrm{Na}$, leading to greater $\mathrm{Na}$-induced calciuria and PTH secretion. In our study subjects were normotensive and, thus, could have been less likely to have enhanced PTH secretion and enhanced bone resorption. None of the previous studies on postmenopausal women have evaluated the possible differential response to $\mathrm{Na}$ loading in normotensive and hypertensive subjects. Most studies used normotensive subjects (Castenmiller et al. 1985; McParland et al. 1989; Zarkadas et al. 1989; Chan et al. 1992), but others did not mention the blood pressure of their subjects (Breslau et al. 1985; Need et al. 1991).

Plasma Mg fell with $\mathrm{Na}$ loading, and there was a tendency for urinary $\mathrm{Mg}$ to increase, suggesting that $\mathrm{Na}$ may also influence $\mathrm{Mg}$ metabolism. Very little is known about the control of Mg homeostasis (Lemann, 1993), but PTH administration has been shown to depress plasma $\mathrm{Mg}$ without significant effect on urinary $\mathrm{Mg}$ (Slovik et al. 1981). Osteoporotics have been found to have lower serum $\mathrm{Mg}$ levels that controls (Reginster et al. 1989), and the role of $\mathrm{Mg}$ in bone metabolism has been neglected (Seelig, 1990).

In summary, the present study, using a recently-developed sensitive marker of bone resorption, has shown that no direct change in bone resorption occurred in postmenopausal women when $\mathrm{Na}$ intake changed from 60 to $170 \mathrm{mmol} / \mathrm{d}$. A further study, using DPD as a marker, is needed to test whether postmenopausal women with hypertension or an initial $\mathrm{Na}$ : creatinine value greater than $15 \mathrm{mmol} / \mathrm{mmol}$ are likely to show an increase in bone turnover under conditions known to induce hypercalciuria. In addition, there is evidence that $\mathrm{Na}$ intake may affect $\mathrm{Mg}$ metabolism. 
We thank the Analytical Department of The Rowett Research Institute, M. Annand, A. Duncan and J. S. Milne, for their help in the analytical work and L. Massie and M. Addison who provided the diets for the volunteers. We also thank M. Franklin for his statistical advice. This study was supported by the Scottish Office, Agriculture and Fisheries Department.

\section{REFERENCES}

Bauder, P. J. (1981). Affinity and stoichiometry of calcium binding by arsernazo III. Analytical Biochemistry 110, 61-72.

Bolton-Smith, C., Smith, C. S., Woodward, M. \& Turnstall-Pedoe, H. D. (1991). Nutrient intakes of different social-class groups: results from the Scottish Heart Health Study (SHHS). British Journal of Nutrition 65 , 321-335.

Breslau, N. A., McGuire, J. L., Zerwekh, J. E. \& Pak, C. Y. (1982). The role of dietary sodium on renal excretion and intestinal absorption of calcium and on vitamin D metabolism. Joumal of Clinical Endocrinology and Metabolism 55, 369-373.

Breslau, N. A., Sakhaee, K. \& Pak, C. Y. (1985). Impaired adaptation to salt-induced urinary calcium losses in postmenopausal osteoporosis. Transactions of the Association of American Physicians 98, 107-115.

Castenmiller, J. J., Mensink, R. P., van der Heijden, L., Kouwenhoven, T., Hautvast, J. G., de Leeuw, P. W. \& Schaafsma, G. (1985). The effect of dietary sodium on urinary calcium and potassium excretion in normotensive men with different calcium intakes. American Journal of Clinical Nutrition 41, 52-60.

Chan, E. L., Ho, C. S., MacDonald, D., Ho, S. C., Chan, T. Y. \& Swaminathan, R. (1992). Interrelationships between urinary sodium, calcium, hydroxyproline and serum PTH in healthy subjects. Acta Endocrinologica 127, 242-245.

Colwell, A., Eastell, R., Assiri, A. M. \& Russell, R. G. (1990). Effect of diet on deoxypyridinoline excretion. In Proceedings of the 3rd International Symposium on Osteoporosis, pp. 590-591 [C. Christiansen and K. Overgaard, editors]. Copenhagen: Osteopress ApS.

Delmas, P. D. (1992). Clinical use of biochemical markers of bone remodeling in osteoporosis. Bone 13, S17S21.

Department of Health (1991). Dietary Reference Values for Food Energy and Nutrients for the United Kingdom. London: H.M. Stationery Office.

Eyre, D. (1992). Editorial: New biomarkers of bone resorption. Journal of Clinical Endocrinology and Metabolism 74, 470A-470C.

Gitelman, H. J., Hurt, C. \& Ludwak, L. (1966). An automated spectrophotometric method for magnesium analysis. Analytical Biochemistry 14, 106-120.

Grinspoon, S. K., Baum, H. B. A., Kim, V., Coggins, C. \& Klibanski, A. (1995). Decreased bone formation and increased mineral dissolution during acute fasting in young women. Joumal of Clinical Endocrinology and Metabolism 80, 3628-3633.

Lawes Agricultural Trust (1987) Genstat V. Rothamsted, Herts: Lawes Agricultural Trust.

Lemann, J. (1993). Urinary excretion of calcium, magnesium, and phosphorus. In Primer on the Metabolic Bone Diseases and Disorders of Mineral Metabolism, pp. 50-55 [M. J. Favus, editor]. New York: Raven Press.

McCarron, D. A., Rankin, L. I., Bennett, W. M., Krutzik, S., McClung, M. R. \& Luft, F. C. (1981). Urinary calcium excretion at extremes of sodium intake in normal man. American Journal of Nephrology 1, 84-90.

MacGregor, G. A. \& Cappuccio, F. P. (1993). The kidney and essential hypertension: a link to osteoporosis? Journal of Hypertension 11, 781-785.

McLaren, A. M., Isdale, A. H., Whiting, P. H., Bird, H. A. \& Robins, S. P. (1993). Physiological variations in the urinary excretion of pyridinium crosslinks of collagen. British Journal of Rheumatology 32, 307-312.

McParland, B. E., Goulding, A. \& Campbell A. J. (1989). Dietary salt affects biochemical markers of resorption and formation of bone in elderly women. British Medical Journal 299, 834-835.

Ministry of Agriculture, Fisheries and Food (1991). Household Food Consumption and Expenditure 1990. London: H.M. Stationery Office.

Need, A. G., Morris, H. A., Cleghorn, D. B., Nichilo, D. D. Horowitz, M. \& Nordin, B. E. C. (1991). Effect of salt restriction on urine hydroxyproline excretion in postmenopausal women. Archives of International Medicine 151, 757-759.

Nordin, B. E. C. \& Polley, K. J. (1987). Metabolic consequences of the menopause. Calcified Tissue International 41, Suppl. 1, S1-S60.

Pesce, A. \& Kaplan, L. A. (1987). Methods in Clinical Chemistry, pp. 1021. St Louis, MO: C. V. Mosby Co.

Pratt, D. A., Daniloff, Y., Duncan, A. \& Robins, S. P. (1992). Automated analysis of the pyridinium crosslinks of collagen in tissue and urine using solid-phase extraction and reversed-phase high-performance liquid chromatography. Analytical Biochemistry 207, 168-175. 
Ray Sarkar, B. C. \& Chauhan, U. P. (1967). A new method for determining micro quantities of calcium in biological materials. Analytical Biochemistry 20, 155-166.

Reginster, J. Y., Strause, L., Deroisy, R., Lecart, M. P., Saltman, P. \& Franchimont, P. (1989). Preliminary report of decreased serum magnesium in postmenopausal osteoporosis. Magnesium 8, 106-109.

Robins, S. P. (1982). Turnover and crosslinking of collagen. In Collagen in Health and Disease, pp. 160-178 [J. B. Weiss and M. I. Jayson, editors]. Edinburgh: Churchill Livingstone.

Robins, S. P., Black, D., Paterson, C. R., Reid, D. M., Duncan, A. \& Seibel, M. J. (1991). Evaluation of urinary hydroxypyridinium crosslink measurements as resorption markers in metabolic bone diseases. European Joumal of Clinical Investigation 21, 310-315.

Seelig, M. S. (1990). Increased need for magnesium with the use of combined oestrogen and calcium for osteoporosis treatment. Magnesium Research 3, 197-215.

Shortt, C., Madden, A., Flynn, A. \& Morrissey, P. A. (1988). Influence of dietary sodium intake on urinary calcium excretion in selected Irish individuals. European Journal of Clinical Nutrition 42, 595-603.

Shortt, S. \& Flynn, A. (1990). Sodium-calcium inter-relationships with specific reference to osteoporosis. Nutrition Research Reviews 3, 101-115.

Slovik, D. M., Neer, R. M. \& Potts, J. T. (1981). Short-term effects of synthetic human parathyroid hormone-(134) administration on bone mineral metabolism in osteoporotic patients. Journal of Clinical Investigation 68 , 1261-1271.

Smith, W. C., Crombie, I. K., Tavendale, R. T., Gulland, S. K. \& Tunstall-Pedoe, H. D. (1988). Urinary electrolyte excretion, alcohol consumption and blood pressure in the Scottish Heart Health Study. British Medical Journal 297, 229-230.

Southgate, D. A. T. (1969). Determination of carbohydrates in food II.-Unavailable carbohydrates. Journal of the Science of Food and Agriculture 20, 331-335.

Stevens, D. L., Skeggs, L. T., Casson, A. L., Grady, H. J. \& Stanley, M. A. (1953). Modification of the procedure of Folin and Wu. In Practical Physiological Chemistry, p. 506 [P. B. Hawk, B. L. Oser and W. H. Summerson, editors]. Philadelphia: Blakiston.

Technicon Instruments Co. Ltd (1971). Auto Analyzer Sheet no. 11-07. Basingstoke: Technicon Instruments Co. Ltd.

Zarkadas, M., Gougeon Reyburn, R., Marliss, E. B., Block, E. \& Alton Mackey, M. (1989). Sodium chloride supplementation and urinary calcium excretion in postmenopausal women. American Joumal of Clinical Nutrition 50, 1088-1094. 